\title{
Synergism between Erwinia pectate lyase isoenzymes that depolymerize both pectate and pectin
}

\author{
Stefan Bartling, ${ }^{1,2}$ Christina Wegener ${ }^{2}$ and Ole Olsen ${ }^{1}$
}

Author for correspondence: Stefan Bartling (Carlsberg Laboratory). Tel: +453327 53 33. Fax: +4533 274766. e-mail: bartling@biobase.dk

1 Carlsberg Laboratory, Department of Physiology, Gamle Carlsberg Vej 10, DK-2500 Copenhagen, Denmark

2 Federal Centre for Breeding Research on Cultivated Plants, Institute for Stress Physiology and Quality of Raw Materials, Institutsplatz, D-18190 Gross Lüsewitz, Germany

\begin{abstract}
Phytopathogenic Erwinia bacteria cause tissue maceration by secretion of pectinolytic enzymes such as pectate lyase (PL). Sequencing of overlapping genomic fragments from Erwinia carotovora subsp. atroseptica established the organization of a 7.5 kbp region encoding PL isoenzymes. Two intergenic regions of 656 and 645 bp separate three enzyme coding regions of 1125 bp exhibiting approximately $80 \%$ positional identity. The promoters of each of the three genes contain a segment with high homology to the binding sequence of the $E$. chrysanthemi KdgR transcription repressor, implying similar mechanisms of gene regulation in the two bacterial species. Separate expression of the pel genes in the Escherichia coli-pT7-7 system and purification of their products yielded PLs at 7-33 $\mathrm{g}(\mathrm{I} \text { culture) })^{-1}$ with greater than $95 \%$ purity. Availability of the recombinant enzymes allowed determination of the kinetic differences amongst the PL isoforms, PL1, PL2 and PL3. The results show that PL is not strictly confined to depolymerization of pectate since each isoenzyme more readily degrades $31 \%$ esterified pectin. Addition of isoenzyme combinations revealed no synergism with respect to degradation of pectate or $31 \%$ esterified pectin. However, addition of enzyme combinations containing PL3 enhanced the activity towards $68 \%$ esterified pectin, against which individual PL activities were low, by up to $64 \%$. These data suggest that the combination of PL isoenzymes extends the range of pectic substrates which the bacterium can degrade.
\end{abstract}

Keywords: pectate lyases, synergism, isoenzymes, Erwinia

\section{INTRODUCTION}

Plant pectic substances have a major function in cell-wall cementing in the middle lamellae between adjacent primary cell walls and can be regarded as filler substances within the primary cell wall (reviewed by Varner \& Lin, 1989). Accordingly, depolymerization of pectic components causes cell separation, release of cell-wall-bound proteins and leakage of electrolytes from protoplasts resulting in cell lysis. Phytopathogenic bacteria of the genus Erwinia penetrate and colonize plant tissues causing

Abbreviations: Eca, Erwinia carotovora subsp. atroseptica; Ecc, Erwinia carotovora subsp. carotovora; Ech, Erwinia chrysanthemi; PG, polygalacturonase; $\mathrm{PGA}$, polygalacturonic acid; $\mathrm{PL}$, pectate lyase; $\mathrm{PME}$, pectin methylesterase; PNL, pectin lyase.

The EMBL accession number for the nucleotide sequences of the three pel genes reported in this paper is $X 81847$. soft-rot diseases by pectolytic, cellulolytic and proteolytic degradation of host cell walls (Pérombelon \& Kelman, 1980). Given the complex and variant structure of pectin, its enzymic degradation is accomplished by the synergistic action of enzymes such as pectin methylesterase (PME), pectin lyase (PNL), polygalacturonase (PG) and pectate lyase (PL). Bacterial synthesis of enzyme isoforms may additionally help to ensure the degradation of pectin in a variety of environments or provide a more advantageous regulatory strategy to the bacteria.

PLs, which play a major role among the pectolytic enzymes (Collmer \& Keen, 1986), have been distinguished from PNLs by their specificity for pectate, and not pectin, although both enzymes degrade their substrate by $\beta$-elimination resulting in an unsaturated C-4-C-5 bond at the nonreducing end of the $\alpha-1,4$ linked products (Rombouts \& Pilnik, 1980). Despite the 
differences, sequence comparisons imply similarities between the three-dimensional enzymic structures (Yoder et al., 1993). Several homologous and recombinant PL enzymes have been purified for use in tissue maceration analyses, but there are limited data available regarding their mode of action, and it has not yet been determined whether pectins of intermediate esterification could function as substrate for PL.

Erwinias synthesize isoenzymic forms of PL encoded by multiple pel genes. In Erwinia chrysanthemi (Ech), five separate genes and their products have been characterized (Koutoujansky et al., 1985; Reverchon et al., 1986), while the genome of $E$. carotovora subsp. carotovora $(E c c)$ has been shown to encode four PLs (reviewed by Koutoujansky, 1987). Previous studies disagreed on the number of PLs in E. carotovora subsp. atroseptica (Eca), which primarily causes soft-rot and blackleg diseases of potatoes (Pérombelon \& Kelman, 1980). Enzyme purification or isoelectric focusing of concentrated culture fluids indicated the presence of three (Ried \& Collmer, 1986) or six (George et al., 1991) PL isoenzymes, while McMillan et al. (1992) purified two isoenzymes which were secreted into the culture medium. No gene sequences have been reported. However, two and three genes encoding PLs were cloned from E. carotovora EC (Lei et al., 1987, 1988) and E. carotovora Er (Yoshida et al., 1992). The EMBL Data Library (release 40) included a total of 49 entries for gene sequences encoding PLs. Among these are plant genes for enzymes which have been hypothesized to participate in pollen tube growth in tomato (Wing et al., 1989) and tobacco (Rogers et al., 1992).

To further analyse the molecular basis for the degradation of pectic substances by Eca, we have undertaken characterization of the pel genes and the corresponding gene products. We report here the genomic sequence spanning three pel genes encoding PL isoenzymes. Each gene was separately expressed in Escherichia coli, and active enzyme purified and characterized. Interestingly, the results revealed that the highly homologous PLs depolymerize both pectate and pectin. Combinations of the enzymes were accordingly examined for synergism towards various pectins.

\section{METHODS}

Bacteria, vectors and culture conditions. Eca strain $\mathrm{C} 18$, propagated at $25^{\circ} \mathrm{C}$ in Luria Bertani (LB) medium, was from the culture collection of the Institute for Stress Physiology and Quality of Raw Materials, Germany. E. coli strains used were DH $5 \alpha$ (Gibco-BRL) and BL21(DE3)pLysS (Novagen). Vectors were pUC18 (Vieira \& Messing, 1982) and pT7-7 (Studier $c t a l$., 1990). E. coli were grown at $37^{\circ} \mathrm{C}$ in LB medium or, to facilitate purification of the recombinant PL enzymes, in M9 medium (Sambrook et al., 1989) supplemented with $100 \mu \mathrm{g}$ ampicillin $\mathrm{ml}^{-1}$ for transformed DH5 $\alpha$ cells or $100 \mu \mathrm{g}$ ampicillin $\mathrm{ml}^{-1}$ and $25 \mu \mathrm{g}$ chloramphenicol ml ${ }^{-1}$ for BL21(DE3)pLysS cells.

DNA isolations and sequencing. Standard procedures were used for purification of bacterial chromosomal DNA, digestion with restriction endonucleases, ligation and transformation, and amplification of DNA using PCR, as described by Sambrook $e t$ al. (1989). Genomic DNA purified from Eca C18 was partially digested with Sau3AI. Following electrophoresis in a $0.8 \%$ agarose gel, DNA fragments of $2-4 \mathrm{kbp}$ were recovered using Prep-A-Gene (Bio-Rad), ligated into pUC18 linearized with Bam HI and propagated in E. coli DH5 $\alpha$. After growth on LBagar plates containing $0.4 \%$ citrus pectin (P-9135, Sigma), zones with enzymically degraded pectin remained clear upon staining with $0.05 \%$ ruthenium red. Plasmid DNA from clones synthesizing active PL was purified using the Wizard System (Promega) or the Maxi Plasmid Kit (Qiagen) according to the suppliers' instructions. Sequencing of both DNA strands utilized a model 373A DNA Sequencer (Applied Biosystems). Computer analysis of DNA and protein sequences was carried out using the MicroGenie software (Beckman).

Expression and purification of recombinant PLs. The coding regions of $p e l 1, p e l 2$ and $p e l 3$ were amplified by PCR using primers incorporating sequences for cloning into PT7-7 (Studier et al., 1990). DNA sequencing confirmed the identity of each insert. E. coli BL21(DE3)pLysS cells harbouring the respective expression vectors were propagated in a 101 Bioreactor (MBR). At $\mathrm{OD}_{600} 0 \cdot 4-0.8$, the culture was made $0.4 \mathrm{mM}$ in isopropyl $\beta$-D-thiogalactopyranoside to induce synthesis of PL. The culture fluid containing secreted PL was separated from the cells by filtration using Minicross (Microgon) membranes. Remaining PL was liberated from the periplasmic space of the concentrated cells by multiple freeze-thaw cycles, and subsequently combined with the culture fluid before ultrafiltration and concentration utilizing a Pellicon (Millipore) cassette. After anion-exchange chromatography using diethylaminoethyl cellulose DE53 (Whatman), unbound proteins were concentrated in a Minitan (Millipore) filtration unit and chromatographed on a S-Sepharose (Pharmacia) cation-exchange column. Elution was performed by applying a combined $\mathrm{pH} /$ salt gradient ( $20 \mathrm{mM}$ sodium acetate, $\mathrm{pH} 5.0$ to $20 \mathrm{mM}$ Tris $/ \mathrm{HCl}$, pH 8.0 , and 0 to $500 \mathrm{mM} \mathrm{NaCl}$ ). The fractions exhibiting PL activity were combined and subjected to gel-filtration chromatography employing Superdex 200 (Pharmacia).

Protein concentration determinations and electrophoresis. Protein concentrations were determined by dye-binding, using bovine serum albumin as a standard (Bradford, 1976). Enzyme purity was assessed by SDS-PAGE (Laemmli, 1970) using $12.5 \%(\mathrm{w} / \mathrm{v}$ ) ExcelGel (Pharmacia) polyacrylamide gels. Protein bands were visualized by staining with Coomassie Brilliant Blue R-250. Isoelectric focusing of the purified PLs employed Isogel $\mathrm{pH} 3-10$ (FMC) agarose gels according to the manufacturer's instructions.

$\mathrm{N}$-terminal amino acid sequencing. The purified PL isoenzymes were sequenced by automated Edman degradation in a model 470A Sequenator (Applied Biosystems); 100 pmol of the individual enzymes were used.

Enzyme assays, substrate specificity analysis and synergism studies. All measurements of PL activity were performed at least in triplicate. Product formation was followed continuously in a computer-assisted model 8452A (Hewlett-Packard) diode array spectrophotometer equipped with a thermostat. Unless otherwise indicated, the experiments were carried out at $25^{\circ} \mathrm{C}$ during time courses of $2-5 \mathrm{~min}$ by monitoring the increase in $A_{236}$ caused by the formation of unsaturated products released during the enzymic degradation of polygalacturonic acid (PGA) (P-1879, Sigma). Activity on pectin was determined by using a similar procedure but substituting $31 \%, 68 \%$ or $93 \%$ esterified citrus pectin (P-9311, P-9436, P-9561, Sigma) for PGA. An increase of $5 \cdot 2 A_{236}$ units $\mathrm{min}^{-1}$ corresponds to the formation of $1 \mu \mathrm{mol}$ unsaturated products $\mathrm{min}^{-1}$ (Nasuno \& Starr, 1966) or one enzyme unit (EU). To avoid alkaline breakdown of the pectic compounds, the substrate was freshly prepared immediately prior to the measurements by dissolving it in $100 \mathrm{mM}$ 
Tris/ $\mathrm{HCl}, \mathrm{pH} 8.5$ (pH 8.0 for PL2), $0.1 \mathrm{mM} \mathrm{CaCl}_{2}$. Enzyme samples of $15 \mu \mathrm{l}$ containing $0.04 \mathrm{EU}$ were added to solutions containing $985 \mu \mathrm{l}$ substrate. To reduce measurement of unspecific disintegration of pectin, recordings were initiated after $30 \mathrm{~s}$ of preincubation. For determination of $K_{\mathrm{m}}$ and $V_{\max }$ values, the PL isoenzymes were incubated with $0 \cdot 02-0 \cdot 10 \%(\mathrm{w} / \mathrm{v})$ PGA or $31 \%$ esterified pectin. The choice of the temperature for measurements of kinetic data $\left(45^{\circ} \mathrm{C}\right)$ was a compromise between the optimum for PL1 and PL3 $\left(40^{\circ} \mathrm{C}\right)$ and that for PL2 $\left(50^{\circ} \mathrm{C}\right)$. Subsequent calculations employed the direct linear plot according to Cornish-Bowden \& Eisenthal (1978); $0 \cdot 1 \%$ (w/v) substrate was used for analyses of substrate specificity and synergism.

Scanning electron microscopy. The individual PLs were infiltrated by vacuum into potato (Solanum tuberosum) tuber discs of $30 \mathrm{~mm}$ diameter and $5 \mathrm{~mm}$ thickness. Each enzyme was applied at $2 \mathrm{EU} \mathrm{ml}^{-1}$. After $30 \mathrm{~min}$ incubation at $25^{\circ} \mathrm{C}$, the macerated tissue was washed five times with deionized water. The separated cells were air-dried and examined by scanning electron microscopy employing a Rem-Cam Scan 44 microscope.

\section{RESULTS AND DISCUSSION}

\section{Structural organization of the pel genes}

Previous work has shown that Eca produces at least three PL isoenzymes (Ried \& Collmer, 1986). However, the structural organization of the corresponding genes was

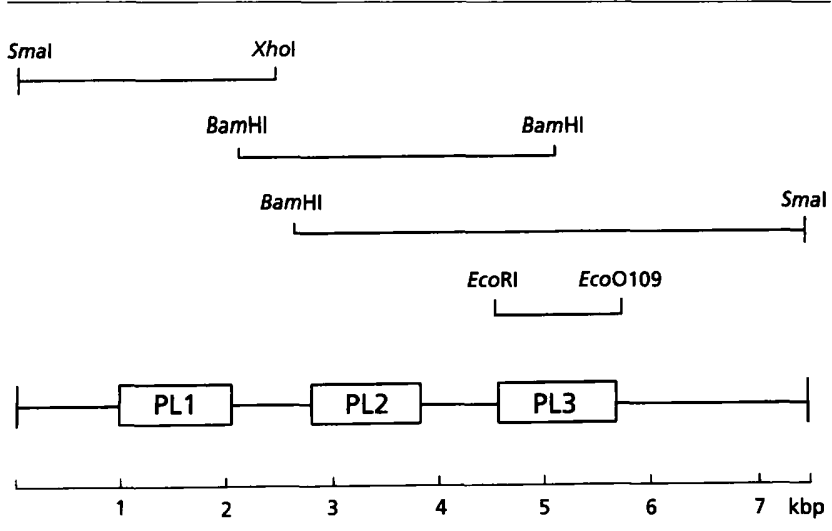

Fig. 1. Genetic organization of a $7.5 \mathrm{kbp}$ region of Eca. Open reading frames encoding three isoenzymes are demarcated by open boxes. The locations of restriction sites used for cloning of individual gene fragments are indicated. not analysed. Expression cloning using E. coli as host for plasmids directing synthesis of active Eca PLs followed by alignment of four overlapping cloned DNA fragments allowed the establishment of the primary structure for a contiguous sequence of $7.5 \mathrm{kbp}$ encoding three PL isoenzymes (Fig. 1), each consisting of 374 amino acids. Alignment of the enzyme-coding regions revealed a homology of around $80 \%$, with the differences randomly scattered throughout the sequences. Unlike $E c h$, in which one of the two pel gene clusters encodes an acidic PL (PL A) and two alkaline forms (PL D and PL E), the triple gene cluster unveiled in $E_{c a}$ encodes three alkaline forms (see below). The tandem organization has also been described for Erwinia genes encoding proteases (Boyd \& Keen, 1993) and Out proteins (Reeves et al., 1993). However, the functional significance for this tandem arrangement remains elusive. Given that isoelectric focusing may resolve isoenzymes derived from minor posttranslational modifications, e.g. N-terminal modification, deamidation or phosphorylation, the results also agree well with previous analyses employing isoelectric focusing of Eca-synthesized PLs, where the presence of at least three and possibly six extracellular isoforms was identified (George et al., 1991). Similarly, three isoenzymes have been identified in the closely related bacterium Ecc (Ried \& Collmer, 1986).

The DNA sequence of the individual pel genes $5^{\prime}$ to the ATG translation initiation codons is shown in Fig. 2. A typical ribosome-binding sequence (RBS) precedes each start codon, while segments exhibiting homology with binding sequences for prokaryotic -35 and -10 transcription factors (Studnicka, 1987) are located further upstream. The low homology of the -10 region with the consensus sequence could suggest binding by a special sigma factor (Harley \& Reynolds, 1987). Together, these results indicate that each gene constitutes a single independent transcription unit. This is further supported by the presence of sequences with high homology to the identified consensus sequence for the binding of the $E c b$ KdgR transcription repressor (Nasser et al., 1994), which negatively regulates several genes encoding enzymes involved in pectin degradation (Hugouvieux-Cotte-Pattat \& Robert-Baudouy, 1992). The appearance of common regulatory sequences suggests that factors controlling transcriptional activity of pel genes are shared by the Eca and $E c b$ bacteria. Thus, as in Ech, the Eca pel genes are likely to be inducible by growth on pectin-containing media (Condemine et al., 1986). pell
pel2
pel3

GGCTITATAGACAAACCTTATTTTCATTTTTGTTGAAACAGCCTTTTTAAATTACACA GGGTGTG TAG T GATAAATACCC AAAAAATCTAIGTCAAGGAGAGTAC ATAATG GGTTITTCAC CAAAATTGAAATTCATTTITGTTGAAAAA TTTACACTTGTTACATC GGGCATAG GGATCGATAAATGCCC ATGAAAATTCTAITCCAAGGAGACAGTGATAATG GGGAITTCA ATAAACCTTGATTTCATTTTTATTGAAACA CCAAAATAATATA ATCTGGGTIATGTGGAT CATAAATGCCCAAACAAAAATTCTATTCCAAGGAGAGTACCCTAATG $\operatorname{KdgR}(62-77 \%) \quad \overline{-35(100 \%)}$ $-10(50 \%)$ RBS (100\%)

Fig. 2. Control regions for pel expression in Eca. The underlined sequences indicate putative KdgR (repressor of genes encoding pectolytic enzymes) binding sites (Condemine \& Robert-Baudouy, 1991), (-35, -10$)$ promoter motifs and ribosome-binding sites (RBS; Studnicka, 1987). The percentages given below the underlined sequences denote the degree of homology to the consensus sequences, in the case of the KdgR binding sites referring to the consensus established by Nasser et al. (1994). 

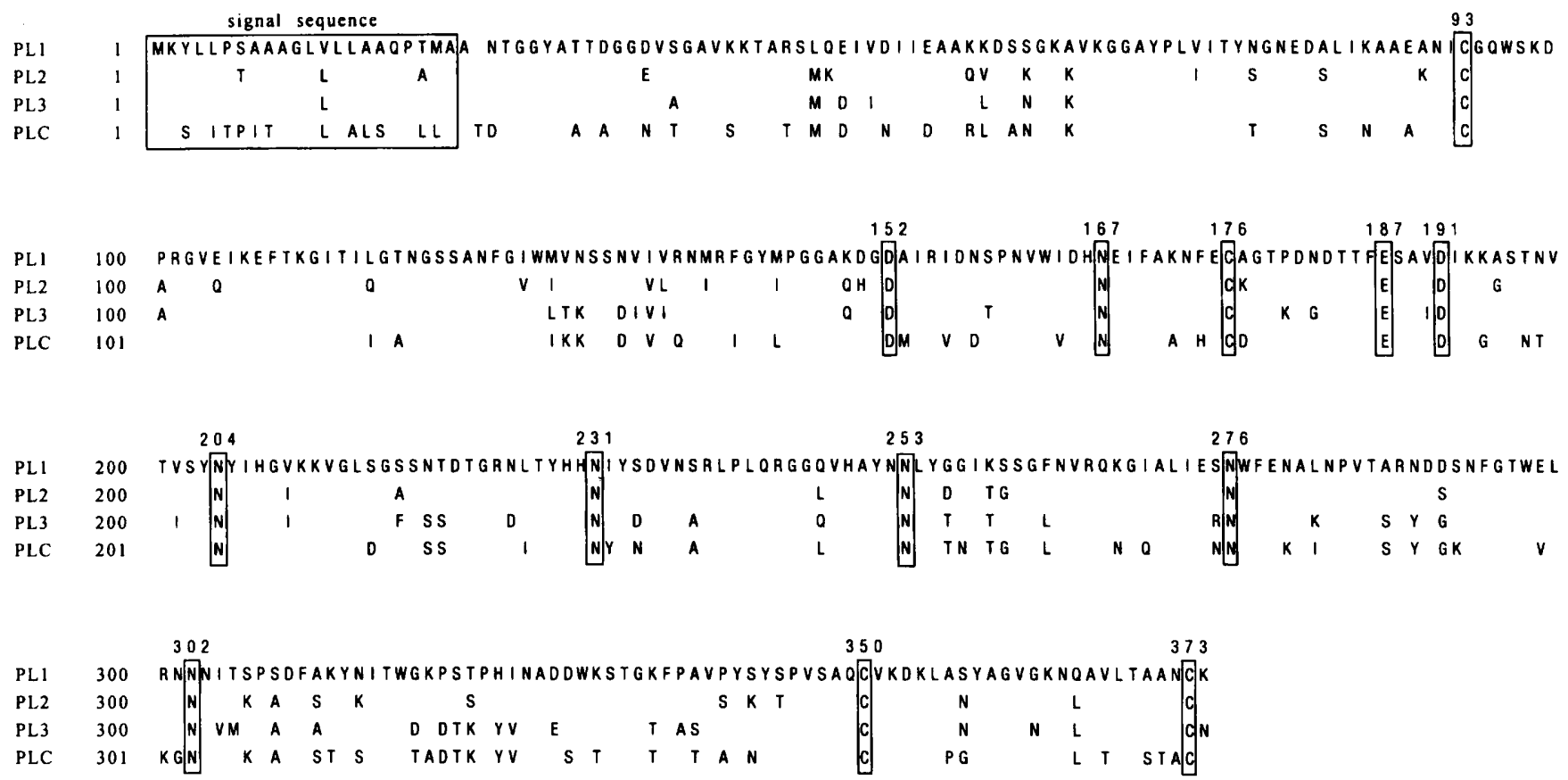

Fig. 3. PL amino acid sequence analysis. The deduced sequences of Eca PL1, PL2 and PL3 are shown together with that of Ech PL C (Tamaki et al., 1988). Except for the signal sequence, conserved amino acids (defined as those important for structure and function in Ech PL C; Yoder et al., 1993) are boxed.

\section{Protein homology and structure}

Alignment of the deduced protein sequences unveiled homologies of $88.3 \%, 85.9 \%$ and $81.9 \%$ for PL1:PL2, PL1:PL3 and PL2:PL3, respectively (Fig. 3). When compared with the protein sequence of Ech PL C, which has been crystallized and found to fold into a novel domain motif designated the parallel $\beta$-helix (Yoder $e t$ al., 1993), all three PL isoenzymes exhibit conserved residues which have been identified as important for enzyme integrity. Thus, there are four Cys residues in positions $93,176,350$ and 373 , indicating the presence of two disulphide bonds. Linear stacks of amino acids, including a novel asparagine ladder, form the core of the Ech PL C. The Asn residues of the ladder are also conserved throughout the Eca PL isoenzymes (Fig. 3). Moreover, the residues Asp-131, Glu-166 and Asp-170, suggested by Yoder et al. (1993) to be involved in $\mathrm{Ca}^{2+}$ binding essential for PL activity, correspond to Asp-152, Glu-187 and Asp191, respectively, in the Eca PLs. Major differences between Ech PL C and the investigated Eca enzymes are confined to regions assigned to loop structures protruding from the central core of the enzymes. Accordingly, PLs synthesized and secreted by Eca are expected to fold into a conformation similar to the Ech PL C counterpart.

\section{Purification of recombinant PL isoenzymes}

The conservation in Eca of three genes encoding PL raised questions regarding the functional significance of three isoenzymes. Differences in isoenzymic properties can be expected to elucidate factors contributing to the depolymerization of various complex plant pectin substances.

In order to obtain pure enzyme, the protein-coding region of each pel gene was amplified by PCR and placed under transcriptional control of the strong $\mathrm{T} 7$ bacteriophage $\phi 10$ promoter in the pT7-7 vector (Studier et al., 1990). While PL1 and PL3 were properly expressed in E. coli, synthesis of PL2 was only obtained with a plasmid construct containing the coding region inverted with respect to the $\phi 10$ promoter. Suitable RBS and $(-10$, $-35)$ promoter motifs were identified in the lower strand of the pT7-7 polylinker region (data not shown), and can apparently effect transcription and translation of pel2.

PL1, PL2 and PL3 were purified to homogeneity from concentrated 101 cultures by ion-exchange chromatography followed by gel-filtration chromatography. The procedure yielded $159 \mathrm{mg}$ PL1, $78 \mathrm{mg}$ PL2 and $330 \mathrm{mg}$ PL3, corresponding to recoveries of $18 \%, 11 \%$ and $15 \%$, respectively.

Analysis of the first $15 \mathrm{~N}$-terminal residues of the purified enzymes resulted in sequences corresponding to residues 23-37 deduced from the DNA sequences. The absence of secondary sequences in the preparations confirmed their purity (data not shown). Given the close relationship between the Gram-negative enterobacteria E. coli and $E c a$, these results indicate that PL1, PL2 and PL3 are synthesized as pre-proteins in their homologous host. The 22-residue sequences preceding the mature $\mathrm{N}$-termini (Fig. 3) resemble typical signal sequences with a charged $\mathrm{N}$-terminus, a central hydrophobic core and a processing 


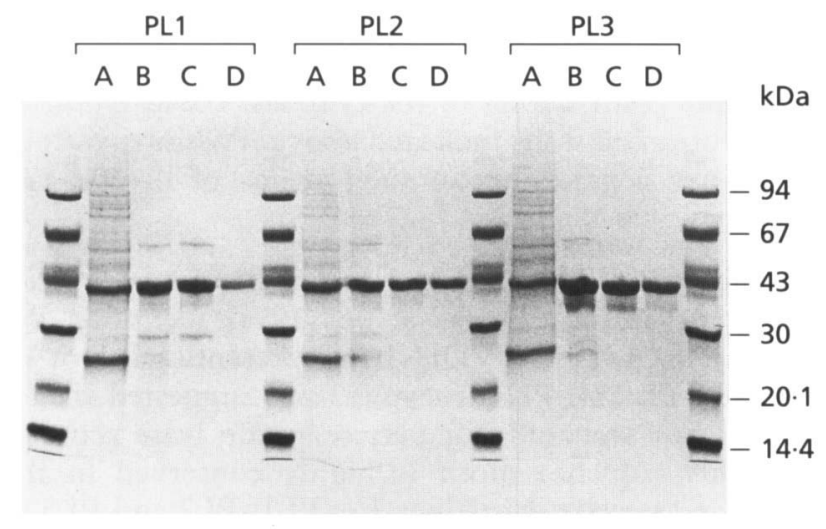

Fig. 4. Protein purification. SDS-PAGE analysis following expression of Eca PL1, PL2 and PL3 in E. coli. Lanes: A, combined culture fluid and filtered cell contents; B, unbound fraction after DE53 anion-exchange chromatography; $C$, protein fraction eluted from S-Sepharose cation-exchange column chromatography; $D$, protein fraction after Superdex $200 \mathrm{gel}$ filtration. Molecular mass standards are indicated.

site consistent with the $(-3,-1)$ rule for signal peptidase cleavage (von Heijne, 1985). The high conservation of the signal sequences, with 22,21 or 20 identical residues among the three enzymes, is notable.

SDS-PAGE under reducing conditions of purified PL1, PL2 and PL3 yielded single protein bands that corresponded to a molecular mass of $42 \mathrm{kDa}$ (Fig. 4). A mass of $38 \mathrm{kDa}$ has been calculated from the deduced amino acid sequences. Similar divergences have also been reported for other PL enzymes, e.g. Ech PL E (Tamaki et al., 1988) and PL A (Favey et al., 1992). Assuming that Eca PLs fold into a compact stable structure similar to Ech PL C(Yoder et al., 1993), this would suggest that undenatured local structural elements of the PLs result in lower enzyme mobilities during electrophoresis.

Isoelectric focusing revealed a $\mathrm{pI}$ of $>10$, similar to the basic Ecb PLs (Ried \& Collmer, 1986). Ech also secretes PL A with a pI of $4 \cdot 6$, exhibiting poor maceration activity on potato tuber tissue, but yet being essential for unlimited bacterial pathogenicity (Favey et al., 1992). The functional implication for the absence of an acidic PL isoform in Eca remains to be elucidated.

\section{Substrate specificities of Eca PL isoenzymes}

In plant cell walls, mainly in the middle lamellae, chemically diverse pectic substances are abundantly present (reviewed by Varner \& Lin, 1989). Detailed analyses of potato tuber cell walls revealed pectic substances to account for approximately $50 \%$ of the total cell wall material. Around $20 \%$ of these pectins were found to be $43 \%$ esterified (Weber, 1976). Their unesterified form, i.e. pectate, is considered the natural substrate for PL. Highest enzymic activity towards this compound was measured at $50^{\circ} \mathrm{C}$ and $\mathrm{pH} 8.0$ for PL2, while PL1 and PL3 had a temperature optimum of $40^{\circ} \mathrm{C}$ at $\mathrm{pH} 8.5$. The

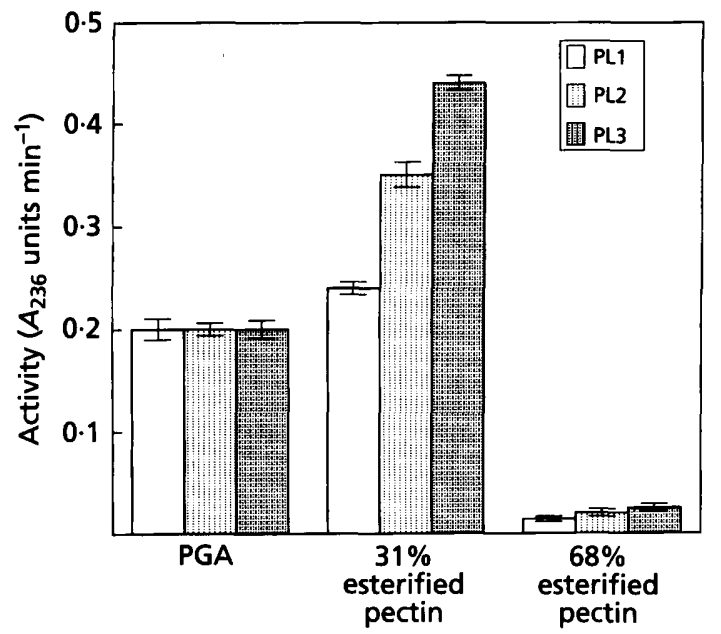

Fig. 5. Effect of substrate on enzyme activity. PL activities were measured towards PGA and citrus pectin. An activity of $0.04 \mathrm{EU}$ of isoenzyme, corresponding to an increase in $A_{236}$ of $0.2 \mathrm{~min}^{-1}$ when utilizing PGA as substrate, was applied to each reaction mixture. No activity could be determined towards $93 \%$ esterified citrus pectin. The values shown are the mean \pm SE of three separate determinations.

amount of products formed by the individual enzymes at $45^{\circ} \mathrm{C}$ was virtually identical to that obtained at the respective temperature optima. Moreover, thermoinactivation experiments revealed $>80 \%$ residual activity for each enzyme after $5 \mathrm{~min}$ incubation at $45^{\circ} \mathrm{C}$ (data not shown). The $K_{\mathrm{m}}$ values were found to be $0.27 \mathrm{mg} \mathrm{ml}^{-1}$ for PL1 and PL3, and $0.30 \mathrm{mg} \mathrm{ml}^{-1}$ for PL2, similar to the $K_{\mathrm{m}}$ values of 0.20 and $0.32 \mathrm{mg} \mathrm{m}^{-1}$ for Ech PL B and PL C (Schoedel \& Collmer, 1986). PL2 and PL3 displayed almost identical $V_{\max }$ values of 641 and $634 \mu \mathrm{mol} \mathrm{min} \operatorname{mos}^{-1}$ (mg protein) ${ }^{-1}$, while the $V_{\max }$ of $846 \mu \mathrm{mol} \mathrm{min}^{-1}$ (mg protein $)^{-1}$ for PL1 hints at a significantly higher activity towards PGA for this enzyme.

Differences were also observed between the isoenzymes in the time courses of pectate depolymerization. PL1 displayed the highest initial velocity, which levelled off rapidly. While PL3 degraded less substrate in the first $80 \mathrm{~s}$, the total degradation after $165 \mathrm{~s}$ of incubation was higher. The time course for degradation of pectate by PL2 was between those of PL1 and PL3. Although the results from the kinetic analyses were obtained by in vitro assays employing pure enzymes and substrates under defined conditions, it seems likely that they reflect the situation in vivo.

Further examination of depolymerization using various esterified pectins supported this assumption. Unexpectedly, application of identical amounts of enzyme units to PGA and esterified pectins revealed a significantly higher efficiency in degradation of pectin with $31 \%$ esterification (Fig. 5). Despite its low $V_{\max }$ value towards the PGA substrate, PL3 turned out to be more active than PL1 and PL2 in depolymerizing pectin with $31 \%$ esterification. Superiority was by $45 \%$ and $24 \%$, re- 

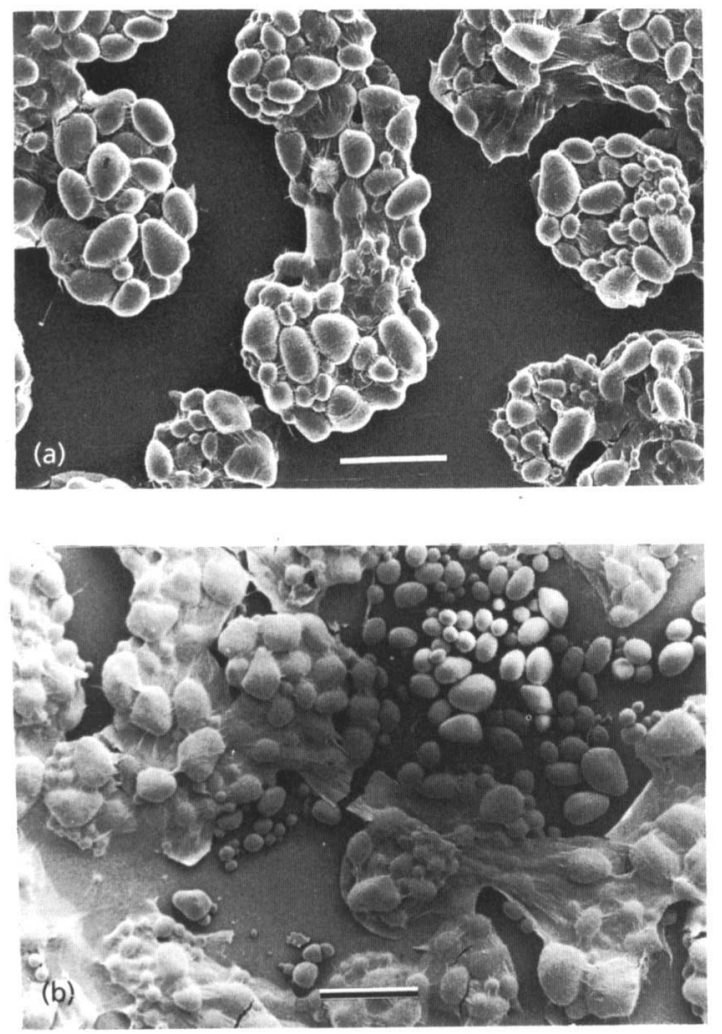

Fig. 6. Scanning electron micrographs of potato tuber tissue after incubation with recombinant PLs. Application of the individual enzymes caused different forms of cell wall breakdown. (a) Separation of tuber cells after degradation of the middle lamellae by the action of PL3. (b) The action of PL1 (and PL2, not shown) causes total tissue maceration with liberation of the cell contents, including starch granules. Bars, $100 \mu \mathrm{m}$.

spectively. Also pectin with $68 \%$ esterification was attacked by the three enzymes, albeit less efficiently (Fig. 5), PL3 again being more active than the other two isoforms. No degradation of pectin with $93 \%$ esterification could be detected. The $K_{\mathrm{m}}$ value towards $31 \%$ esterified pectin was $0.20 \mathrm{mg} \mathrm{ml}^{-1}$ for PL1 and PL2 and $0.10 \mathrm{mg} \mathrm{ml}^{-1}$ for PL3; the corresponding $V_{\max }$ values were 1228,1041 and $2115 \mu \mathrm{mol} \mathrm{min}^{-1}(\mathrm{mg} \text { protein })^{-1}$, indicating higher affinities to pectin than to pectate. Further evidence for the novel finding that the PLs depolymerize pectin more actively than pectate was provided by examination of electron micrographs (Fig. 6 and Wegener et al., 1994). Separate application of the three Eca PLs to potato tuber tissue not only degraded the middle lamellae, but also effected disintegration of pectic components localized in the primary cell wall. The isoenzymes exhibited differences in degradation activity of potato tuber pectic material depending on the plant variety used. PL3 was the least active isoenzyme towards esterified pectins of the potato cell walls, resulting in a breakdown of the middle lamellae. In contrast, incubation of tuber tissue with PL1 or PL2 gave rise to disintegration of single cells and liberation of the cell contents. These results support the notion that Eca PLs in vivo exhibit major affinities to pectins of intermediate esterification, specifically contributing to the chemical composition of potato tuber cell walls indicated above. Possibly, various isoenzymes degrade pectin subdomains of diverse cell wall types.

Based on an extensive comparison of PL enzymes from various organisms, Barras et al. (1994) identified the sequence (S/A/T)-hWVDH-h (h representing I, L or V) in several PL and PNL enzymes, and suggested that it qualifies as a signature for pectate/pectin lyase activity. Since this sequence motif is highly conserved in the pectin- and pectate-degrading Eca PL1, PL2 and PL3 at positions 159-169 (Fig. 3), other subtle amino acid substitutions in substrate binding or catalytic residues may explain the differences in their substrate specificities. This is supported by recent results describing significant alterations in substrate affinities, acquired by changes of only amino acid side chains in the substrate-binding groove of two $\beta$-glucanases giving hydrolysis of either $(1 \rightarrow 3)$ - or $(1 \rightarrow 3,1 \rightarrow 4)$ - $\beta$-glucan (Varghese et al., 1994).

Involvement of Erwinia PL isoenzymes in degradation of pectin was unexpected as the bacteria secrete PME, a deesterifying enzyme initially removing methoxyl groups from pectins (Rexová-Benková \& Markovic, 1976). Its action yields methanol and PGA, which in turn is accessible to PGs and PLs (Plastow, 1988). Presumably, the action of PME occurs primarily towards highly esterified pectins (degree of esterification $>60 \%$ ) or in concert with PG at the onset of pathogenesis. Due to alterations in environmental conditions during the progress of plant tissue degradation, an increase from $\mathrm{pH} 5 \cdot 0$ to $\mathrm{pH} 8.5$ would accompany inactivation of PG (optimal activity for Ecc PG is at pH 5.5; Saarilahti et al., 1990). Further pectin depolymerization possibly depends on the action of $\mathrm{PL}$ isoforms exhibiting affinities towards pectins, although an increase of $\mathrm{pH}$ in a continuing plant degradation could not be detected (data not shown). Thus, secretion of PL isoforms may be a specific adaptation of Eca to its main host plant potato and its numerous varieties. It remains to be established if similar enzyme specificities are characteristic for other Erwinia species. However, it has been suggested that Ech PL A partially depolymerized $20 \%$ esterified pectin (Favey et al., 1992), while the E. carotovora EC153 pel153 gene product preferred polypectate to pectin as substrate (Trollinger et al., 1989).

\section{Synergistic action between Eca PLS}

Synergism is evident not only between enzymes utilizing identical substrates (e.g. cellulases; Irwin et al., 1993; Vincken et al., 1994), but also among enzymes with different specificities. For degradation of cell walls, strong synergism was found between pectolytic and cellulolytic enzymes (Renard et al., 1991a, b). Since naturally occurring pectins are structurally heterogeneous in their side chain composition, degree of esterification and linkage frequency, synergism among pectolytic enzymes 
Table 1. Depolymerization of PGA and pectin by PL isoenzyme combinations

Equal enzymic activities giving a total of $0.04 \mathrm{EU}$ were applied to the substrate, followed by measuring the activity $\left(A_{236} \mathrm{~min}^{-1}\right)$. The expected activities are derived from the individual enzymic activities (data not shown). Values for synergism are calculated by dividing the measured activity by the expected activity; values $>1$ indicate positive synergism. Results are the means \pm SE of at least three measurements.

\begin{tabular}{|c|c|c|c|c|c|c|c|c|c|}
\hline \multirow{3}{*}{$\begin{array}{l}\text { Enzyme } \\
\text { combination }\end{array}$} & \multicolumn{9}{|c|}{ Substrate: } \\
\hline & \multicolumn{3}{|c|}{ PGA } & \multicolumn{3}{|c|}{$31 \%$ esterified pectin } & \multicolumn{3}{|c|}{$68 \%$ esterified pectin } \\
\hline & $\begin{array}{l}\text { Activity } \\
\text { measured }\end{array}$ & $\begin{array}{l}\text { Activity } \\
\text { expected }\end{array}$ & $\begin{array}{l}\text { Syner- } \\
\text { gism }\end{array}$ & $\begin{array}{l}\text { Activity } \\
\text { measured }\end{array}$ & $\begin{array}{l}\text { Activity } \\
\text { expected }\end{array}$ & $\begin{array}{l}\text { Syner- } \\
\text { gism }\end{array}$ & $\begin{array}{l}\text { Activity } \\
\text { measured }\end{array}$ & $\begin{array}{l}\text { Activity } \\
\text { expected }\end{array}$ & $\begin{array}{l}\text { Syner- } \\
\text { gism }\end{array}$ \\
\hline PL1/PL2 & $0 \cdot 177 \pm 0 \cdot 020$ & $0 \cdot 198 \pm 0 \cdot 013$ & $0 \cdot 89$ & $0 \cdot 229 \pm 0 \cdot 013$ & $0.292 \pm 0.009$ & 0.78 & $0.022 \pm 0.0015$ & $0.023 \pm 0.0009$ & 0.96 \\
\hline PL1/PL3 & $0.213 \pm 0.040$ & $0.215 \pm 0.013$ & 0.99 & $0 \cdot 263 \pm 0.010$ & $0.365 \pm 0.005$ & 0.72 & $0.037 \pm 0.0016$ & $0.027 \pm 0.0015$ & $1 \cdot 37$ \\
\hline PL2/PL3 & $0 \cdot 181 \pm 0.011$ & $0 \cdot 218 \pm 0 \cdot 007$ & $0 \cdot 83$ & $0 \cdot 290 \pm 0 \cdot 020$ & $0.401 \pm 0.013$ & 0.73 & $0 \cdot 033 \pm 0 \cdot 0014$ & $0.025 \pm 0.0020$ & $1 \cdot 32$ \\
\hline PL1/PL2/PL3 & $0 \cdot 187 \pm 0 \cdot 012$ & $0 \cdot 204 \pm 0 \cdot 012$ & 0.92 & $0 \cdot 231 \pm 0.009$ & $0 \cdot 347 \pm 0 \cdot 020$ & 0.67 & $0 \cdot 041 \pm 0 \cdot 0013$ & $0 \cdot 025 \pm 0.0005$ & 1.64 \\
\hline
\end{tabular}

displaying either identical or different modes of action might facilitate pectin depolymerization (RexováBenková \& Markovic, 1976). To test this possibility it was examined what effect exogenous PLs would have on the depolymerization of pectin.

All possible enzyme combinations were added to solutions containing either PGA or pectin, followed by determination of product formation. Table 1 shows that no increased activities were detected when using PGA or $31 \%$ esterified pectin. The measurements gave activity values of $70-90 \%$ of the sum of the single enzyme activities. Although the monoenzymic degradation of $68 \%$ esterified pectin was low compared to the less esterified compounds, combination of some PLs revealed significantly enhanced depolymerization of the substrate. Interestingly, synergism only occurred in enzyme combinations containing PL3, resulting in up to $64 \%$ increase in activity. PL1 and PL2 together showed no higher degradation of pectin compared to depolymerization by the individual enzymes (Table 1). The closer linkage and length of the substrate side chains may influence enzymic breakdown and emphasize differences in substrate binding or cleavage specificities between the PL isoforms. It is noteworthy that an exo-acting PL from $E c h$ has been suggested to cleave highly esterified pectin (Brooks et al., 1990). A similar enzyme is probably present in Eca, where it may function in concert with PLs to promote efficient degradation of pectin.

More detailed information was obtained by examining the time-course for product formation following degradation of pectin with enzyme combinations (Fig. 7). PL1 and PL2 together caused high initial activities followed by significant reduction after around $150 \mathrm{~s}$. No increase of product formation was obtained when the reaction mixture was supplemented with additional PL1 or PL2 enzyme after $165 \mathrm{~s}$, suggesting exhaustion of available substrate. On the other hand, supplementation with PL3, either initially or after $165 \mathrm{~s}$, produced a significant

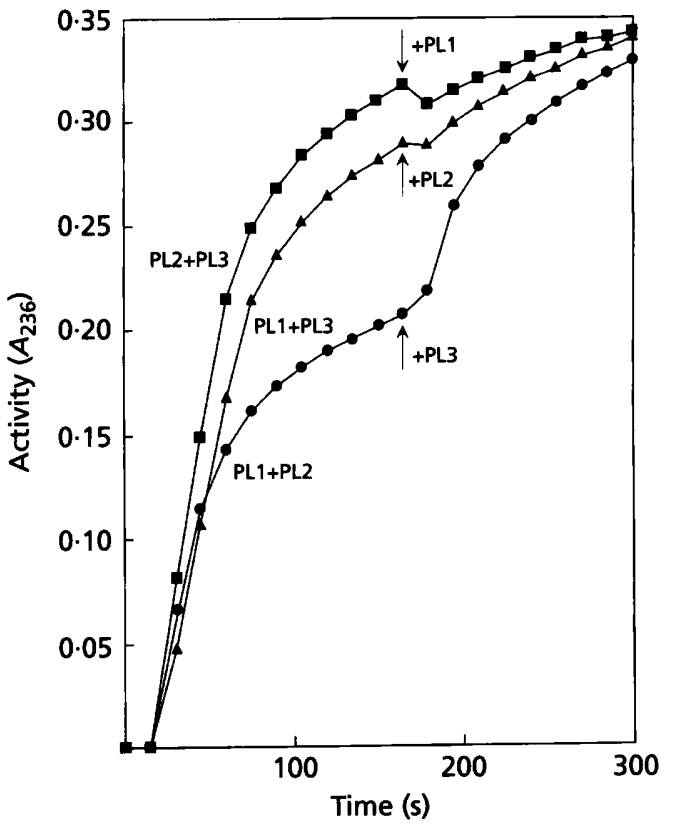

Fig. 7. Depolymerization of $68 \%$ esterified pectin. The reactions were initiated by applying combinations of two PLs, each isoenzyme at a concentration of $0.12 \mathrm{EU}: 0, \mathrm{PL1}$ and PL2; $\Delta, \mathrm{PL} 1$ and PL3;, PL2 and PL3. Arrows indicate addition of the third isoenzyme at a concentration of $0.12 \mathrm{EU}$. Further amounts of enzyme added did not result in enhanced degradation of pectin. Individual points represent the mean of three measurements differing by less than $5 \%$.

enhancement of pectinolysis. These data show that PL1 and PL2 generate products which can be further degraded by PL3, implying differences in substrate binding and action patterns among the isoenzymes, with PL3 being less affected by steric features of the substrate, such as esterification and sidechain length. Because of the relatively low activity towards $68 \%$ esterified pectin, it 
remains to be established if these observations are of significance for the degradation of pectin in vivo.

\section{Multiplicity of PLs}

The reason why erwinias have acquired multiple genes encoding PLs is an intriguing question. It could be argued that pectate, which has been supposed to be the natural substrate for PL, is chemically homogeneous and therefore would not necessitate multiple enzymes for its degradation. Multiple genes encoding PL could, however, result in elevated synthesis of the required enzymes for efficient depolymerization of pectate. Alternatively, it seems likely that the various PL isoenzymes hydrolyse $\alpha$ $(1 \rightarrow 4)$ bonds situated in different physical environments within the heterogeneous cell wall pectin. This is supported by our results showing that not only do the Eca PL isoenzymes depolymerize pectin of intermediate esterification more efficiently than pectate (Fig. 5), but they also reveal synergism for degradation of $68 \%$ methylated pectin (Table 1). The results obtained by measuring product formation following addition of multiple purified PL isoenzymes to pectate or pectin (Table 1, Fig. 7) imply that PL1 and PL2 produce substrates for the action of PL3, the multiple genes thus providing the organism with selective advantages.

Several compounds function as inducers for expression of Ech pel genes (summarized by Sauvage \& Expert, 1994). Among these are pectate oligomers and polymers. Since our results indicate differences in the action of PL isoenzymes, it will be of interest to study the effect on pel gene expression of adding specific pectic products to $E c a$ cultures.

\section{ACKNOWLEDGEMENTS}

Diter von Wettstein is thanked for support and encouragement, Ib Svendsen for protein sequencing and Rainer Bahlow, Institut für Ostseeforschung, Rostock, Germany, for electron microscopic investigations. Eva Gertman is acknowledged for excellent technical assistance. Financial support was provided by the FEI (Forschungskreis der Ernährungsindustrie e.V., Bonn, and the Ministry of Economics, Germany, project no. AIF 103D).

\section{REFERENCES}

Barras, F., van Gijsegem, F. \& Chatterjee, A. K. (1994). Extracellular enzymes and pathogenesis of soft-rot Erwinia. Annu Rev Phytopathol 32, 201-234.

Boyd, C. \& Keen, N. T. (1993). Characterization of the prt A and prt B genes of Erwinia chrysanthemi EC16. Gene 133, 115-118.

Bradford, M. M. (1976). A rapid and sensitive method for the quantitation of microgram quantities of protein utilizing the principle of protein-dye binding. Anal Biochem 72, 248-254.

Brooks, A. D., He, S. Y., Gold, S., Keen, N. T., Collmer, A. \& Hutcheson, S. W. (1990). Molecular cloning of the structural gene for exopolygalacturonate lyase from Erwinia chrysanthem $i$ EC16 and characterization of the enzyme product. $J$ Bacteriol 172, 6950-6958.

Collmer, A. \& Keen, N. T. (1986). The role of pectic enzymes in plant pathogenesis. Annu Rev Pbytopatbol 24, 383-409.
Condemine, G. \& Robert-Baudouy, J. (1991). Analysis of an Erwinia cbrysanthemi gene cluster involved in pectin degradation. Mol Microbiol 5, 2191-2202.

Condemine, G., Hugouvieux-Cotte-Pattat, N. \& Robert-Baudouy, J. (1986). Isolation of Erwinia chrysanthemi kduD mutants altered in pectin degradation. J Bacteriol 165, 937-941.

Cornish-Bowden, A. \& Eisenthal, R. (1978). Estimation of Michaelis constant and maximum velocity from the direct linear plot. Biochim Biopbys Acta 523, 268-272.

Favey, S., Bourson, C., Bertheau, Y., Koutoujansky, A. \& Boccara, M. (1992). Purification of the acidic pectate lyase and nucleotide sequence of the corresponding gene (pel A) of Erwinia cbrysanthemi strain 3937. J Gen Microbiol 138, 499-508.

George, H. L., Mount, M. S. \& Berman, P. M. (1991). Cellular localization and characterization of pectic enzymes of Erwinia carotovora subsp. atroseptica. Phytopatbology 81, 134-139.

Harley, C. B. \& Reynolds, R. P. (1987). Analysis of Escherichia coli promoter sequences. Nucleic Acids Res 15, 2343-2357.

Hugouvieux-Cotte-Pattat, N. \& Robert-Baudouy, J. (1992). Analysis of the regulation of the pel $\mathrm{BC}$ genes in Erwinia chrysanthemi 3937. Mol Microbiol 6, 2363-2376.

Irwin, D. C., Spezio, M., Walker, L. P. \& Wilson, D. B. (1993). Activity studies of eight purified cellulases: specificity, synergism, and binding domain effects. Biotechnol Bioeng 42, 1002-1013.

Koutoujansky, A. (1987). Molecular genetics of pathogenesis by soft-rot erwinias. Annu Rev Pbytopathol 25, 405-430.

Koutoujansky, A., Diolez, A., Boccara, M., Bertheau, Y., Andro, T. \& Coleno, A. (1985). Molecular cloning of Erwinia chrysanthemi pectinase and cellulase structural genes. EMBO J 4, 781-785.

Laemmli, U. K. (1970). Cleavage of structural proteins during the assembly of the head of bacteriophage T4. Nature 227, 680-685.

Lei, S.P., Lin, H.-C., Wang, S.-S., Callaway, J. \& Wilcox, G. (1987). Characterization of the Erwinia carotovora pel $\mathrm{B}$ gene and its product pectate lyase. J Bacteriol 169, 4379-4383.

Lei, S.-P., Lin, H.-C., Wang, S.-S. \& Wilcox, G. (1988). Characterization of the Erwinia carotovora pel A gene and its product pectate lyase A. Gene 62, 159-164.

McMillan, G. P., Johnstone, D. J. \& Pérombelon, M. C. M. (1992). Purification to homogeneity of extracellular polygalacturonase and isoenzymes of pectate lyase of Erwinia carotovora subsp. atroseptica by column chromatography. J Appl Bacteriol 73, 83-86.

Nasser, W., Reverchon, S., Condemine, G. \& Robert-Baudouy, J. (1994). Specific interactions of Erwinia chrysanthemi $\mathrm{KdgR}$ repressor with different operators of genes involved in pectinolysis. $J$ Mol Biol 236, 427-440.

Nasuno, S. \& Starr, M. P. (1966). Polygalacturonase of Erwinia carotovora. J Biol Chem 241, 5298-5306.

Perombelon, M. C. M. \& Kelman, A. (1980). Ecology of the soft rot Erwinias. Annu Rev Pbytopathol 18, 361-387.

Plastow, G. S. (1988). Molecular cloning and nucleotide sequence of the pectin methyl esterase gene of Erwinia chrysanthem $i$ B 374. Mol Microbiol 2, 247-254.

Reeves, P. J., Whitcombe, D., Wharam, S., Gibson, M., Allison, G., Bunce, N., Barallon, R., Douglas, P., Mulholland, V., Stevens, S., Walker, D. \& Salmond, G. P. C. (1993). Molecular cloning and characterization of 13 out genes from Erwinia carotovora subspecies carotovora: genes encoding members of a general secretion pathway (GSP) widespread in Gram-negative bacteria. Mol Microbiol 8, 443-456.

Renard, C. M. G. C., Searle-van Leeuwen, M. J. F., Voragen, A. G. J., Thibault, J.-F. \& Pilnik, W. (1991a). Studies on apple 
protopectin. II. Apple cell wall degradation by pure polysaccharidases and their combinations. Carbobydr Polymers 14, 295-314.

Renard, C. M. G. C., Schols, H. A., Voragen, A. G. J., Thibault, J.-F. \& Pilnik, W. (1991b). Studies on apple protopectin. III. Characterization of the material extracted by pure polysaccharidases from apple cell walls. Carbobydr Polymers 15, 13-32.

Reverchon, S., Van Gijsegem, F., Rouve, M., Koutoujansky, A. \& Robert-Baudouy, J. (1986). Organization of a pectate lyase gene family in Erwinia chrysanthemi. Gene 49, 215-224.

Rexová-Benková, L. \& Markovic, O. (1976). Pectic enzymes. In Advances in Carbohydrate Chemistry and Biochemistry, vol. 33, pp. 323-385. Edited by R. S. Tipson \& D. Horton. New York: Academic Press.

Ried, J. L. \& Collmer, A. (1986). Comparison of pectic enzymes produced by Erwinia chrysanthemi, Erwinia carotovora subsp. carotovora, and Erwinia carotovora subsp. atroseptica. Appl Environ Microbiol 52, 305-310.

Rogers, H. J., Harvey, A. \& Lonsdale, D. M. (1992). Isolation and characterization of a tobacco gene with homology to pectate lyase which is specifically expressed during microsporogenesis. Plant Mol Biol 20, 493-502.

Rombouts, F. M. \& Pilnik, W. (1980). Pectic enzymes. In Economic Microbiology. Vol. 5: Microbial Enzymes and Bioconversions, pp. 228-282. Edited by A. H. Rose. New York: Academic Press.

Saarilahti, H. T., Heino, P., Pakkanen, R., Kalkkinen, N., Palva, I. \& Palva, E. T. (1990). Structural analysis of the peh A gene and characterization of its protein product, endopolygalacturonase, of Erwinia carotovora subspecies carotovora. Mol Microbiol 4, 1037-1044.

Sambrook, J., Fritsch, E. F. \& Maniatis, T. (1989). Molecular Cloning: A Laboratory Manual, 2nd edn. Cold Spring Harbor, New York: Cold Spring Harbor Laboratory.

Sauvage, C. \& Expert, D. (1994). Differential regulation by iron of Erwinia chrysanthemi pectate lyases: pathogenicity of iron transport regulatory (cbr) mutants. Mol Plant-Microbe Interact 7, 71-77.

Schoedel, C. \& Collmer, A. (1986). Evidence of homology between the pectate lyase-encoding pel B and pel C genes in Erwinia cbrysanthemi. J Bacteriol 167, 117-123.

Studier, F. W., Rosenberg, A. H., Dunn, J. J. \& Dubendorff, J. W. (1990). Use of T7 RNA polymerase to direct expression of cloned genes. Methods Enzymol 185, 60-89.

Studnicka, G. M. (1987). Nucleotide sequence homologies in control regions of prokaryotic genomes. Gene 58, 45-57.
Tamaki, S. J., Gold, S., Robeson, M., Manulis, S. \& Keen, N. T. (1988). Structure and organization of the pel genes from Erwinia chrysanthemi EC16. J Bacteriol 170, 3468-3478.

Trollinger, D., Berry, S. \& Keen, N. T. (1989). Cloning and characterization of a pectate lyase gene from Erwinia carotovora EC153. Mol Plant-Microbe Interact 2, 17-25.

Varghese, J. N., Garrett, T. P. J., Colman, P. M., Chen, L., Høj, P. B. \& Fincher, G. B. (1994). Three-dimensional structures of two plant $\beta$-glucan endohydrolases with distinct substrate specificities. Proc Natl Acad Sci US A 91, 2785-2789.

Varner, J. E. \& Lin, L.-S. (1989). Plant cell wall architecture. Cell 56, 231-239.

Vieira, J. \& Messing, J. (1982). The pUC plasmids, an M13 mp7derived system for insertion mutagenesis and sequencing with synthetic universal primers. Gene 19, 259-268.

Vincken, J.-P., Beldman, G. \& Voragen, A. G. J. (1994). The effect of xyloglucans on the degradation of cell-wall-embedded cellulose by the combined action of cellobiohydrolase and endoglucanases from Trichoderma viride. Plant Pbysiol 104, 99-107.

von Heijne, G. (1985). Signal sequences. The limits of variation. $J$ Mol Biol 184, 99-105.

Weber, J. (1976). Untersuchungen über Zellwandgehalt und -zusammensetzung der Kartoffelknollen. Biochem Physiol Pflanzen 169, 589-594.

Wegener, C., Bartling, S., Thomsen, K. K. \& Olsen, O. (1994). Preferential degradation of middle lamellae by an Erwinia pectate lyase. Abstract, 7th International Symposium on Molecular Plant-Microbe Interactions, 26 June-1 July 1994, University of Edinburgh, UK.

Wing, R. A., Yamaguchi, J., Larabell, S. K., Ursin, V. M. \& McCormick, S. (1989). Molecular and genetic characterisation of two pollen expressed genes that have sequence similarity to pectate lyases of the plant pathogen Erwinia. Plant Mol Biol 14, 17-28.

Yoder, M. D., Keen, N. T. \& Jurnak, F. (1993). New domain motif: the structure of pectate lyase $C$, a secreted plant virulence factor. Science 260, 1503-1506.

Yoshida, A., Matsuo, Y., Kamio, Y. \& Izaki, K. (1992). Molecular cloning and sequencing of the extracellular pectate lyase II gene from Erwinia carotovora Er. Biosci Biotech Biochem 56, 1596-1600.

Received 3 October 1994; revised 19 December 1994; accepted 3 January 1995. 